\title{
Becoming an English Teacher: An Autobiographical Narrative Inquiry
}

\author{
Afrianto Daud \\ DOI: $10.35445 /$ alishlah.v13i1.405
}

Article Info

Keywords:

Narrative inquiry

Becoming a teacher

ENGLISH teacher

Teachers identity
Kata kunci:

Naratifinkuiri

Menjadi guru

Guru bahasa Inggris

Identitas guru

\section{Abstract}

This paper documents a fragment of a story in my life that plays a significant role in shaping my identity as an English teacher and influencing me in deciding to become an English teacher as my career choice. This study's research question is 'how and why did I decide to become an English teacher?'. This study was conducted using the "narrative inquiry" method under the qualitative research paradigm. The study is carried out by describing an individual's life, collecting and retelling parts of his life relevant to the research topic. In this study, the fragments of the story that are retold are the writer's own experience. This study shows that a person's journey to become a teacher can start long before he/she enters a teacher education institution. A person's decision to become a teacher can come internally and come from external factors, such as the influence of 'significant others', socio-cultural factors, economic factors, and teacher political factors. All of these factors are intertwined or influence a person's final decision on whether to choose a career as a teacher or not.

\begin{abstract}
Abstrak
Tulisan ini mendokumentasi penggalan kisah dalam hidup saya yang berperan signifikan dalam pembentukan jati diri saya sebagai guru bahasa Inggris sekaligus yang mempengaruhi saya dalam membuat keputusan memilih jadi guru (dosen) Bahasa Inggris sebagai pilihan karir saya. Pertanyaan penelitian dari studi ini adalah 'bagaimana dan mengapa saya memutuskan menjadi guru Bahasa Inggris'. Kajian ini dilakukan dengan metode 'narative inquiry' di bawah payung paradigma penelitian kualitatif. Kajian dilakukan dengan cara mendeskripsikan kehidupan dari satu individu, mengumpulkan dan menceritakan ulang bagian kehidupannya yang relevan dengan topik penelitian. Dalam studi ini, penggalan kisah yang diceritakan ulang adalah pengalaman penulis sendiri. Kajian ini menunjukkan bahwa perjalanan seseorang menjadi guru bisa dimulai jauh sebelum yang bersangkutan masuk ke lembaga pendidikan guru. Keputusan seseorang menjadi guru bisa muncul secara internal (dari dalam diri seseorang), bisa juga muncul dari faktor eksternal, seperti pengaruh 'significant others', faktor sosial budaya, faktor ekonomi, dan faktor politik keguruan. Keseluruhan faktor ini saling mempengaruhi keputusan akhir seseorang apakah akan menjadi memilih karir sebagai guru atau tidak.
\end{abstract}

Universitas Riau, Pekanbaru, Indonesia

Email: afrianto.a@lecturer.unri.ac.id

Vol.13 (1) June, 2021

Received: February 21, 2021; Received in revised form: March 22, 2021; Accepted: March 23, 2021; Available online: March 30, 2021

This is an open access article under a Creative Commons Attribution-NonCommercial-ShareAlike 4.0 International License 


\section{INTRODUCTION}

The process of becoming a teacher, including becoming an English teacher, is timeconsuming and unpredictable. The path can be up and down and not linear. The journey may have started long before someone decided to enter formal education as a teacher candidate at the Institution for Teachers and Education (LPTK) or other teacher education institutions. The decision to be a teacher could also come after graduates from the preservice teacher education program. The story cannot be generalized. This process can be very personal and will vary from person to person.

Previous studies have attempted to investigate how a person's journey to becoming a teacher in the Indonesian context. Some of the studies focused on the reasons for someone to become a teacher (Afrianto, 2014; Muazza, Mukminin, Aina, Ariyanti, \& Rosmiati, 2016; Tustiawati, 2017). Others focused on the obstacles or obstacles that a person experiences while being a teacher during a teacher education program (Abid, 2018; Widiati, Suryati, \& Hayati, 2018) or teaching practicum program (Afrianto, 2017; Rahayuningsih, 2016; Riesky, 2013; Wempi Pasaka, Emilia, \& Amalia, 2014).

Studies from Afrianto (2014) and Tustiawati (2017), for instance, revealed that there are certain reasons for someone to become a teacher in the Indonesian contexts. Among the most prominent ones is socio-cultural reasons. Becoming a teacher in Indonesia is acknowledged as a noble job. Culturally, teachers are highly respected figures or roles in Indonesia. In Javanese culture, there is a specific term for the teacher 'lan digugu, lan ditiru', literally means people who deserve to be emulated and followed. These two reasons are categorized as altruistic, which are more than just materialistic reasons.

Another study conducted by Suryani and Richardson (2013)found that in addition to what other studies have revealed, such as desiring to contribute to the establishment of future generations, they also found out that among other reasons Indonesian students choose to become teachers is because of job security. Some of the participants thought that being a teacher was a job that would always exist. It is believed, as long as humans are still learning, of course, they will always need teachers.

This study aims to conduct a narrative inquiry by reflecting on my journey as a person who decided to become an English teacher. Although there have been many studies with a narrative approach in other parts of the world, so far there have not been many studies related to how a person chooses to become an English teacher written using a narrative method in the Indonesian context (Hapsari \& Ena, 2019; Soekirno, 2004 are some exceptions). Thus, this paper seeks to fill the existing gaps from the methodological aspects related to this theme.

\section{METHODS}

This paper focuses on answering two questions: 1) How was my journey until finally deciding to become an English teacher?; 2) What factors influenced me when I decided to become an English teacher?

This paper was conducted using the narrative inquiry method under the qualitative research paradigm. This is a qualitative research method that was first introduced by Connelly and Clandinin (1990), then was further developed by Clandinin and Huber (2010). The narrative research design focuses on the narrative of the life of an individual.

The basic principle of narrative inquiry is that humans are storytelling organisms who are individually or socially living within their own stories. Therefore, the study of narrative, according to Connelly \& Clandinin (1990) is a study on how humans drive their lives in the world. In educational research, this general concept is refined into the view that education and educational researches are the construction and reconstruction of stories from one individual and a group of people socially. Learners, teachers, and researchers are storytellers and characters in their own stories or tell other people's stories.

The study was conducted by describing an individual's life, collecting and retelling parts of his life relevant to the research topic. As suggested by Given (2008) and Assjari (2010), a good narrative study begins by asking the story of the researcher's experiences because a narrative study 
is an ongoing reflective and reflexive methodology. For this reason, "narrative inquirers need to continually inquire into their experiences before, during, and after each inquiry" (Clandinin \& Caine, 2012, p. 171).

In this study, the fragments of the story that are retold are the researcher's experience. The data was compiled based on reflections of childhood experiences, experiences at school, experiences during teacher education, and after graduating from teacher education. To be more specific, the data were first sorted chronologically from my first exposure to teaching activities during childhood, schooling experience, and after finishing teacher education. Next, the data were sorted according to the identity conflicts that I experienced, whether I would choose teaching as my career or not after graduation from the teacher education program.

All related stories are selected in such a way, then analyzed by juxtaposing and comparing the stories with relevant theories in teacher education. The analysis was done by adopting the idea of "social interaction analysis" (Akinsanya, A., \& Bach, C. (2014).in which the interaction between the author and people in his social circle (such as peers during childhood and schooling, school teachers, parents, and people in general) was carefully examined to find interesting evidence, opinions and facts that could contribute toward this study.

\section{FINDINGS AND DISCUSSION}

\section{First Introduction to Teacher Activities}

After reflecting on my life journey, my first interaction with teacher activities was not when I was studying English at the Institute for Teacher Training and Education (IKIP) in Padang. Still, I studied at Surau (a place like a mosque for Minangkabau people). I was about seven years old in the first grade of elementary school.

Surau is a term used by the Minangkabau, an ethnic group in West Sumatra, Indonesia. Studying in a surau is a good tradition in our village. All school-age children in our village must attend some afternoon school by studying at the mosque, from before sunset to Isha time every day. We call it 'going to the mosque'. In this surau, we learned many things, especially how to read the Qor'an and knowledge of Islamic fiqh (Islamic jurispudence). Regarding the surau education system in the realm of Minang, please read Ondira Asa and Sahrul (2018) and Maimunah (2012).

There were about sixty children who went to study in this surau. We were divided into two classes with different ability levels. There was a beginner class that learned how to read juz amma (chapters for beginner level of Quranic learning). Then, there was an advanced class whose participants were those who had passed juz amma and were focused on learning to read the 'advance Qur'an'. Meanwhile, our Qor'an teacher was only one person. Thus, he must share his attention in guiding these two groups of students with different abilities.

Even though I was the same age as most beginner class students, I quickly joined the advanced class. I had been able to finish juzz amma a little bit faster than most of my friends did. It was probably because of this, one night my teacher said, 'Anto, you, please help me as a teacher assistant. Please teach your friends first when I teach the advanced class.

This is likely my first interaction with a teaching activity or being a teacher. In short, although at first, I was not confident, then I carried out my role as the assistant teacher. It was the first time I stood in front of the class holding chalk and a reading guide stick. I explained and led friends to learn to read juzz amma before our teachers gave us additions and reinforcement.

On the one hand, I felt a new burden to be an assistant teacher because I was appointed with new responsibilities. At the same time, I thought it was an honour given to me, and then I should do my best. I tried to prepare myself before the class came by studying the material that I would convey. Even though at the beginning, I was nervous, however, day by day, I started to enjoy my activities as an assistant teacher.

From the theoretical perspective of being a teacher, what I experienced can be called peer teaching activities. Peer tutoring is generally known as an activity where students teach other 
students or those who act as tutors. Febianti (2014) explains that students who act as tutors are students who dominate other students. In other words, a tutor is a student who is smarter or better understands the subject matter in certain subjects than other students.

The use of peer tutors in this learning process has been quite practised. Several studies have shown that peer tutoring is a practice that is quite effective in helping teachers achieve learning goals (for example, see Haris, 2018; Kavanoz \& Yüksel, 2010). I did not know whether my Qur'an teacher understood this peer teaching theory. What is clear, he had been practising in our surau for nearly forty years ago.

Going back to my childhood story, if I was exposed to teaching activities for the first time when my teacher appointed me to be an assistant teacher, my meeting with a foreigner who came to my village was the story of my initial exposure to English. That was the first time I had direct interaction with a native English speaker. It was the first time I heard how English sounded.

One day a white man visited our village for an activity. I did not understand at all. When he and his team stopped by the shop in our village, some little kids (including me) were gathering around them. Neither of us could speak English at that time. At a glance, what attracted us the most was his different physical appearance. They have fairy skinned, tall, sharp, and spoke a 'weird' language.

Even though I did not understand English, I was happy to hear the foreigners' odd-words and unique language. Suddenly I wondered how cool it would be if I could speak English. The desire to speak English got stronger when the foreigner greeted us in English. Neither of us could answer it. We just smiled and did not know what to say. However, after meeting these foreigners, I dreamed of how cool I would be to speak English.

My meeting with the foreigners, although brief, might be categorized indirectly as $a$ significant another variable in the course of my story as a teacher, especially an English teacher. The term significant others refer to certain individuals who directly or indirectly influence a person to develop into a certain person, or in making important decisions in his life (Andersen, Chen, \& Miranda, 2002). They can be teachers, parents, or certain characters who interact with someone in becoming a teacher.

\section{School days}

Back when I was in school, from elementary to high school, I always motivated teachers at school about the importance of speaking English as a foreign language because English is an international language. English is a necessary language as part of the preparation for globalization. I heard the campaign about the importance of English repeatedly from various parties during my school days. My teachers at school were certainly part of the significant others, which influenced how I saw the importance of English as a foreign language.

The narrative about the importance of English was dominant in teaching foreign languages in Indonesia when I was in school. Many figures argued that English is the power to become an empowered citizen of the world ( see Crystal, 1999; Kachru, 1986; Melitz, 2016; Winkler, 2005). The essence of the messages is that the mastery of English as an international language is indispensable for many people to continue to exist and take part in taking benefit from the trend of globalization. This campaign was very massive, I felt during my school days.

I did realize the importance of English. I then decided to increase my English skills by taking an English course in Bukittinggi (a small town where many tourists visited in West Sumatera). I wen to this private English course to have more learning experiences in addition to learning English at school. Together with my friends, we used to take courses three times a week in the city of Bukitinggi.

Apart from studying formally in class during the course, we used our time to directly practice speaking by looking for foreigners in the upper markets of Bukittinggi. Around the 90s, 
Bukittinggi was a tourist area that foreign tourists very much visited. So it was easy for us to find foreigners to practice English.

Because I was considered to have better English skills, some of my friends then asked me to teach them English in an activity like the English Club at my senior high school. Then, I became an English Club instructor for my friends. This experience of being an English instructor then became the second phase in my life to have the experience of being a teacher.

\section{"Get lost" to the Right Path}

Even though I enjoyed sharing with my friends at the English Club, but at that time, I never thought about becoming an English teacher one day. The typical of my peers-generation, most aspired to be doctors, engineers, lawyers, accountants, and other so-called 'cool professions. Teacher-profession was recognized as a 'second class' profession at that time. Although teachers were still highly respected socially and culturally, teachers were also perceived as a profession of "Oemar Bakri" that was identical to a simple man with a modest salary. This perception has prompted many bright children to refuse to be teachers (Bachtiar, 2015).

As I did not dream of becoming a teacher, when I was about to fill out an invited student form (for university entrance) when I was in high school, I planned to choose a medical major. As an outstanding student in my school, I believed I could be accepted. However, it turned out that I had no right to choose a medical department because I came from a social department. I never knew that to become a medical student. I had to come from a student majoring in Physics or Biology (natural science). Again, I never knew this until I was going to fill out the university entrance form.

Knowing that I was not eligible to choose the medical faculty, I then asked my homeroom teacher what major I should choose. My teacher suggested to 'just join' IKIP (Teacher and Education Institute). "Take the major you like the most. IKIP is good. You can become a teacher later,' he suggested.

Even though I still did not intend to become a teacher, I finally chose to study English at IKIP Padang. I chose this course because I just loved learning English. I thought that my English skills were quite good. So, I chose English not because I wanted to be an English teacher, but because I liked English.

I finally officially became a IKIP Padang student at English Language Education, which later changed its name to Padang State University. I followed all the lectures in this teacher department. I met and learned from many of my great lecturers, alumni from various leading campuses abroad. I studied all the theories of the teaching profession. I also experienced teaching practicum in school placement before I finally achieved my bachelor degree with the best honours.

During my time as IKIP Padang students, my friends and I often heard of 'mockery', which could damage our motivation to become teachers or ruin our image about how noble it is to be teachers. Among the bullyings, for example, we often got questions that may be joking but also insulting, such as the following,

'Dima kuliah, diak?' (Where did you go to college, Brother?)

'UNAND' (Universitas Andalas)

'O, hebat tu!' (O, that's great)

Dima kuliah, diak? (Where did you go to college, Brother?)

Bung Hatta (Universitas Bung Hatta)

$O$, kayo tu! (O, you must be rich)

Dima kuliah, diak? (Where did you go to college, Brother?)

IKIP (Teachers and Education Institute)

$O$, dima kampuang? (Where are you from?) 
The phrase 'dima kampuang'? in Minangkabau language reflects an insult showing that those who come from village areas are identified with poor, low education, or culturally left behind those coming from the city. That insulting question indirectly says that our campus was recognised by people who mostly come from the village or rural people: the poor, the marginalized, and the economically disadvantaged.

Even though I have been through the teacher education process for more than four years and graduated as the best alumnus, I did not immediately think about being a teacher as my career. I still taught that being a teacher is not as cool as other professions. This probably because I was influenced by socially shaped perceptions regarding the teaching profession at that time. Therefore, after graduating, I tried to register and participate in selecting to become an Indonesian diplomat. Becoming a diplomat is one of the cool professions that my generation has dreamed of. I followed the layered selection process. But, I could not make it to the end; I did not pass.

After failing to pass the diplomat selection, a friend invited me to teach at a tutoring institution that was well known in my city at that time. Apart from teaching English, I was also offered to be a manager of the English course unit at his institution. Finally, I complied with my friend's request. I appreciated the offer. When many other people applied to the institution, I was even invited to join.

Since then, I started to focus on starting my career as an English teacher. I lived with the joy and sorrow of teaching students of many backgrounds and ages. I have taught elementary, middle, high school to college students. Then, I focused on pursuing this profession. To date, I have been teaching at several institutions for more than 20 years.

After more than twenty years of teaching, I have now concluded that it seems that I have 'got lost' into the right path. I began to find myself as an educator. I started to enjoy the process of being a real teacher in the field. I want the ups and downs. I understand that being a teacher is more than just an ordinary profession.

The respect and acceptance that students and society gave to me during my time in this profession have made me strong. Acceptance and respect are rewards that cannot be valued in money or financial. I felt this respect primarily when I once had taught at a school far from urban areas. I proved that culturally the teacher is a profession that is respected by society.

Another psychological satisfaction, of course, is when I finished standing in front of the class, guiding students to achieve learning targets. It is a delight to see students understand what I am teaching. It includes reading my student's feedback regarding how they feel after teaching. Their positive responses are among other reinforcements that bring satisfaction to the soul. This is one reason why many teachers persist and remain happy through Indonesia's teaching process even though the reward system is excellent beforehand (see Tiatri \& Tji Beng, 2016).

My acceptance of this profession is getting stronger when the government started to pay attention to teachers and lecturers' welfare. After enacting Law 14/2005 on teachers and lecturers, Indonesia officially recognized that teachers and lecturers were on par with other professions that had already been established in Indonesia. The state then carried out a lot of these teacher professional development programs, including by imposing their salary and incentive systems. One of the programs is the provision of professional allowances for certified teachers and lecturers.

Even though it still cannot be called a high salary, there is an improvement in teachers' wellbeing. So, at least teachers and lecturers can meet their basic needs. Getting these incentives, they are expected to be more focused on improving their learning and teaching quality, including their teaching profession. In the end, it is hoped that it can improve the quality of national education. Although several studies report that this teacher certification program has not had a significant positive impact on the quality of teaching and the quality of national education in general (see Fahmi, Maulana, \& Arief Anshory Yusuf, 2014; Kusumawardhani, 2017; World Bank, 
2015), this program is at least has answered among the classic problems of the teaching profession in Indonesia - the problem of welfare.

Now teachers can focus more on their responsibilities as educators. Although when it comes to money, then it will never have enough. The incentives received by teachers and lecturers should be sufficient to meet their basic needs. Thus, the stories about teachers and lecturers who took on other side jobs are now irrelevant. In the long term, better welfare is expected to impact the quality of teaching, the quality of students, and the quality of education as a whole.

\section{CONCLUSION}

Reflecting on my journey to become a teacher, it can be concluded that a person's decision to become a teacher may be based on several complex considerations and factors. The urge can come internally; it can also come from external factors, such as the influence of interactions with significant others, socio-cultural influences, economic factors, and political factors. In my case, external factors dominated my early days as a teacher. However, I later discovered that I had a great passion for becoming a teacher internally.

The narrative of my journey above also teaches us that the journey to become a teacher is unique and personal. Therefore, mine may not be the same route as other people. Becoming a teacher, including becoming an English teacher, is an idiosyncratic journey, complex, and may not be linear. There will always be negotiations between various factors, a tug of war between several interests; until then one particular factor is stronger than the other.

The findings of this study have implications for the teacher training program in tertiary institutions that the campus needs to continue to find ways so that students who register at the LPTK are students who have aspired to become teachers. Then, the LPTKs also need to design a strengthening program during the educational process so that the interest of prospective teacher students can still grow stronger until they finish their education program at the LPTK. Thus, the curriculum content should not only touch on the skills of "how to teach" (pedagogic) and "what to teach" (content knowledge) but also about "why teaching" (why being a teacher). The last point seems not to have been explored much in the curriculum for teacher education in Indonesia through structured and systematic courses.

\section{REFERENCES}

Abid. (2018). Indonesian Pre-service English Teachers' Perceived Challenges in Improving English Oral Communication Skills. Journal of English Education and Linguistics Studie, 5(2), 147-170.

Afrianto. (2014). "Because teaching is like a plantation of dakwah": Understanding complexities in choosing to be a teacher in Indonesia. Australian Journal of Educational and Developmental Psychology, 14(SPEC. ISS.).

Afrianto, A. (2017). Pre-Service Teachers' Integration into Teachers' Community during Teaching Practicum. International Journal of Educational Best Practices, 1(1), 3 . https://doi.org/10.31258/ijebp.v1n1.p3-18

Akinsanya, A., \& Bach, C. (2014, April). Narrative analysis: The personal experience narrative approach. In ASEE 2014 Zone I Conference.Andersen, S. M., Chen, S., \& Miranda, R. (2002). Significant Others and the Self. Self and Identity, 1(2), 159-168. https://doi.org/10.1080/152988602317319348

Bachtiar, P. P. (2015, July 11). Teacher certification program and social envy. The Jakarta Post. Retrieved from https://www.thejakartapost.com/news/2015/07/11/teacher-certificationprogram-and-social-envy.html

Clandinin, D. J., \& Huber, J. (2010). Narrative Inquiry. In P. Peterson, E. Baker, \& B. B. T.-I. E. of E. (Third E. McGaw (Eds.), International Encyclopedia of Education (pp. 436-441). https://doi.org/https://doi.org/10.1016/B978-0-08-044894-7.01387-7

Clandinin, D. J., \& Caine, V. (2012). Narrative inquiry. In A. A. Trainor \& E. Graue (Eds.), 
Reviewing qualitative research in the social sciences (pp. 166-179). New York: Routledge.

Connelly, F. M., \& Clandinin, D. J. (1990). Stories of Experience and Narrative Inquiry. Educational Researcher, 19(5), 2-14. https://doi.org/10.3102/0013189X019005002

Crystal, D. (1999). The future of Englishes. English Today. https://doi.org/10.1017/So266078400010816

Fahmi, M., Maulana, A., \& Arief Anshory Yusuf. (2014). Teacher Certification in Indonesia : A Confusion of Means and Ends Working Paper in Economics and Development Studies Department of Economics Teacher Certification in Indonesia : A Confusion of Means and Ends Mohamad Fahmi , Achmad Maulana, and Arief Ans. Retrieved from https://www.researchgate.net/publication/254455515_Teacher_Certification_in_Indonesi a_A_Confusion_of_Means_and_Ends

Febianti, Y. N. (2014). Peer Teaching (Tutor Sebaya) Sebagai Metode Pembelajaran Untuk Melatih Siswa Mengajar. Edunomic Jurnal Ilmiah Pendidikan Ekonomi, 2(2), 80-87. Retrieved from http://www.fkip-unswagati.ac.id/ejournal/index.php/edunomic/article/view/63/61

Given, L. M. (2008). The Sage Encyclopedia of Qualitative Research Methods. United Kingdom: SAGE Publication Ltd.

Hapsari, B. S., \& Ena, O. T. (2019). English Pre-service Teachers' Identity during Teaching Practice: Narrative Research. International Journal of Indonesian Education and Teaching, 3(2), 204-214.

Haris, I. N. (2018). Model Pembelajaran Peer Teaching Dalam Pembelajaran Pendidikan Jasmani. Journal of Chemical Information and Modeling, 4(9), 1689-1699. https://doi.org/10.1017/CBO9781107415324.004

Kachru, B. B. (1986). The power and politics of English. World Englishes. https://doi.org/10.1111/j.1467-971X.1986.tboo720.x

Kavanoz, S., \& Yüksel, G. (2010). An investigation of peer-teaching technique in student teacher development. The International Journal of Research in Teacher Education, 1(3), 10-19. Retrieved from http://ijrte.eab.org.tr/1/spc.issue/1s.hatipoglu.pdf

Kusumawardhani, P. N. (2017). Does teacher certification program lead to better quality teachers? Evidence from Indonesia. Education Economics, 25(6), 590-618. https://doi.org/10.1080/09645292.2017.1329405

Maimunah. (2012). Sistem Pendidikan Surau : Karakteristik, Isi Dan Literatur Keagamaan. Ta'dib, $17(02), 255^{-270 .}$

Melitz, J. (2016). English as a global language. In The Palgrave Handbook of Economics and Language. https://doi.org/10.1007/978-1-137-32505-1

Muazza, Mukminin, A., Aina, M., Ariyanti, T., \& Rosmiati. (2016). Student Teachers' reasons for choosing a Teacher Education Program at one Public University in Indonesia dn Policy Implications. The Online Journal of New Horizons in Education.

Musjafak Assjari, \& Permanarian. (2010). Desain Penelitian Naratif. Jurnal Asesmen Dan Intervensi Anak Berkebutuhan Khusus, 9(2), 172-183.

Ondira Asa, F., \& Sahrul, N. (2018). Kehidupan Surau di Minangkabau sebagai Inspirasi dalam Karya Seni Lukis Abstrak. Gorga Jurnal Seni Rupa, o7(September).

Rahayuningsih, D. (2016). Student teachers' challenges in developing teaching materials during teaching practicum in vocational. Journal of English and Education, 4(2), 24-34. Retrieved from https://ejournal.upi.edu/index.php/L-E/article/view/4629

Riesky. (2013). How English student teachers deal with teaching difficulties in their teaching practicum. Indonesian Journal of Applied Linguistics, 2(2), 250-261. https://doi.org/10.17509/ijal.v2i2.169

Soekirno, D. C. (2004). Phases of awareness: Why I became an English teacher. English Teaching: Practice and Critique, 3(1), 59-70. 
Suryani, A., \& Richardson, H. M. G. W. P. W. (2013). Teaching as a career. Joint AARE Conference, Adelaide 2013, 1-17.

Tiatri, S., \& Tji Beng, J. (2016). Life Satisfaction in Higher Education in Indonesia: A study on Five Older Professors Over 70. The Asian Conference on Education (ACE).

Tsui, A. B. (2007). Complexities of identity formation: A narrative inquiry of an EFL teacher. TESOL Quarterly, 41(4), 657-680. https://doi.org/10.1002/j.154.57249.2007.tboo098.x.

Tustiawati, I. A. M. (2017). What Motivates Pre-service Teachers to Become Teachers and their Perspectives of English Teaching as a Career Option. TEFLIN Journal. https://doi.org/10.15639/teflinjournal.v28i1/38-56

Wempi Pasaka, R., Emi Emilia, \& Amalia, L. L. (2014). The Exploration of Pre-Service EFL Teachers' Challenges in Field Practicum (A Phenomenological Study of Six Pre- service Teachers at a Teacher Preparation Program). International Journal of Education, 7(2), 144-153.

Widiati, U., Suryati, N., \& Hayati, N. (2018). Unraveling the challenges of Indonesian novice teachers of English. Indonesian Journal of Applied Linguistics, 7(3), 621-629. https://doi.org/10.17509/ijal.v7i3.9824

Winkler, E. G. (2005). English as a Global Language (review). Language. https://doi.org/10.1353/lan.2005.0220

World Bank. (2015). Teacher certification and beyond An empirical evaluation of the teacher certification program and education quality improvements in Indonesia. Retrieved from https://openknowledge.worldbank.org/handle/10986/24433 